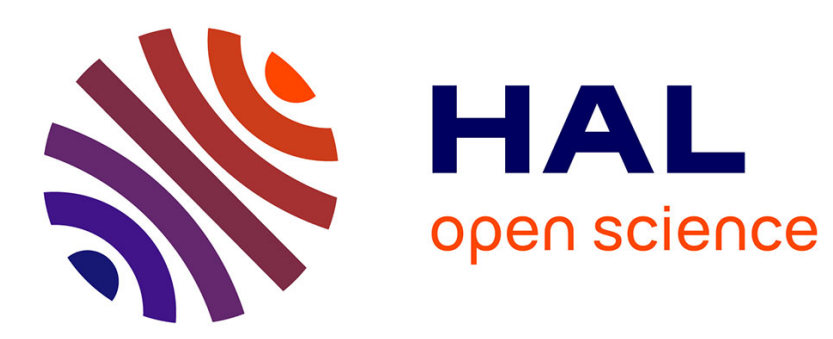

\title{
Regulation of the fructose transporter GLUT5 in health and disease
}

\author{
Véronique Douard, Ronaldo P Ferraris
}

\section{To cite this version:}

Véronique Douard, Ronaldo $\mathrm{P}$ Ferraris. Regulation of the fructose transporter GLUT5 in health and disease. AJP - Endocrinology and Metabolism, 2008, 295 (2), pp.E227-E237. 10.1152/ajpendo.90245.2008 . hal-01606577

\section{HAL Id: hal-01606577 https://hal.science/hal-01606577}

Submitted on 30 May 2020

HAL is a multi-disciplinary open access archive for the deposit and dissemination of scientific research documents, whether they are published or not. The documents may come from teaching and research institutions in France or abroad, or from public or private research centers.
L'archive ouverte pluridisciplinaire HAL, est destinée au dépôt et à la diffusion de documents scientifiques de niveau recherche, publiés ou non, émanant des établissements d'enseignement et de recherche français ou étrangers, des laboratoires publics ou privés. 


\title{
Regulation of the fructose transporter GLUT5 in health and disease
}

\author{
Veronique Douard and Ronaldo P. Ferraris \\ Department of Pharmacology and Physiology, New Jersey Medical School, University of Medicine and Dentistry \\ of New Jersey, Newark, New Jersey
}

Submitted 20 February 2008; accepted in final form 27 March 2008

\begin{abstract}
Douard V, Ferraris RP. Regulation of the fructose transporter GLUT5 in health and disease. Am J Physiol Endocrinol Metab 295: E227-E237, 2008. First published April 8, 2008; doi:10.1152/ajpendo.90245.2008.-Fructose is now such an important component of human diets that increasing attention is being focused on the fructose transporter GLUT5. In this review, we describe the regulation of GLUT5 not only in the intestine and testis, where it was first discovered, but also in the kidney, skeletal muscle, fat tissue, and brain where increasing numbers of cell types have been found to have GLUT5. GLUT5 expression levels and fructose uptake rates are also significantly affected by diabetes, hypertension, obesity, and inflammation and seem to be induced during carcinogenesis, particularly in the mammary glands. We end by highlighting research areas that should yield information needed to better understand the role of GLUT5 during normal development, metabolic disturbances, and cancer.
\end{abstract}

cancer; diabetes; diet; hypertension; inflammation; metabolic syndrome

FOR THOUSANDS OF YEARS, humans consumed about $16-24 \mathrm{~g}$ of fructose each day, mainly as fruits and honey obtained from foraging and agricultural activity. Recent modernization and specialization in agricultural and food processing methods initiated in Europe and North America have altered consumption patterns. Today, the per capita amount of fructose consumed each day ranges from 8 to $100 \mathrm{~g}$, and the average is $\sim 80$ $\mathrm{g} /$ day in the United States $(16,56,86,130)$. Most of the increase in consumption is derived from refined or processed fructose (63).

The chemical process for the rapid commercial conversion of glucose to fructose was developed in 1957 (99), and this technological advance led to the gradual increase in the manufacture and consumption of high-fructose corn syrup (HFCS) (11). HFCS typically contains 42,55 , or $90 \%$ fructose (68). Fructose is the sweetest of all natural sugars, and this is the primary reason why glucose is converted to fructose and why HFCS is used in the formulation of food and beverage products. About 330-380 kcal/day of the energy intake of average Americans (corresponding to $17-20 \%$ of daily energy intake) is derived from fructose (48). Recent studies have shown that there seems to be a direct relationship between increases in consumption of fructose and increases in incidence of obesity and type 2 diabetes $(12,69,114,120)$. High-fructose diets may also lead to the development of "metabolic syndrome," which precedes the onset of type 2 diabetes and is a cluster of symptoms associated with insulin resistance, including dyslipidemia, insulin resistance, impaired glucose homeostasis, increased body fat, and high blood pressure [per reviews $(8,48$, $78,86,130)]$.

The myriad effects of fructose are possible only if fructose reaches physiologically significant concentrations in the

Address for reprint requests and other correspondence: R. P. Ferraris, Dept. of Pharmacology and Physiology, UMDNJ - New Jersey Medical School, 185 South Orange Ave., Newark, NJ 07101. plasma and extracellular fluids and if subsequently transported into cells of various organ systems, thereby potentially altering normal metabolism in those organs. There are marked variations in estimates of blood fructose concentrations arising from differences in methods of collection and analysis. In normal humans, serum fructose concentration was estimated to be $0.008 \mathrm{mM}(80)$, while plasma fructose was $0.030 \mathrm{mM}$ (92). These variations can also arise from differences in fructose consumption, which is a potent regulator of intestinal fructose transport. In rats fed a diet containing glucose as the only carbohydrate source, serum fructose concentrations were $<0.01$ $\mathrm{mM}$, but in those consuming fructose or sucrose, serum fructose concentrations reached $0.10-0.30 \mathrm{mM}$ (19). In healthy humans consuming high-fructose or -sucrose diets, serum fructose can reach $0.2-0.5 \mathrm{mM}(92)$, but this concentration is still very low compared with normal blood glucose levels $(5.5$ $\mathrm{mM})$. This low fructose level results from rates of intestinal absorption lower than that of glucose and from efficient clearance of blood fructose mainly by the liver $(50-70 \%)$ and, to a lesser extent, (20\%) by the kidneys (103).

\section{The Main Fructose Transporter GLUT5}

How does fructose move from the intestinal lumen to the blood and from there to various tissues? Fructose is transported passively across membranes by a member of the facilitative glucose transporter (GLUT) family, named GLUT5 (19, 20, $72,98,137)$. The GLUT family consists of 14 members divided into three major classes based on sequence homology and substrate selectivity, as described in recent reviews (97, 149). The structure and kinetic properties of GLUT5 and other GLUTs will not be reviewed here, nor will fructose transport studies not clearly linked to GLUT5 and GLUT2. Among the seven members able to transport fructose, GLUT5 is the sole transporter specific for fructose with no ability to transport glucose or galactose. It is also insensitive to phloretin and cytochalasin B $(79,97)$. The second major fructose transporter 
is GLUT2, a low-affinity transporter that is also capable of recognizing glucose and galactose, and is inhibitable by phloretin and cytochalasin B (97). GLUT2 in a bidirectional manner is involved mainly in fructose uptake across the hepatic plasma membrane into the liver (154) and in the basolateral membrane of the intestinal and renal epithelial cells (88). Five other GLUTs may possess varying degrees of fructose selectivity based on sequence homology with GLUT5: GLUT7, GLUT9a/b, GLUT8, GLUT11, and GLUT12 (43, 90, 96).

GLUT5 was cloned almost 20 years ago and was initially described as a glucose transporter (9) until its specificity for fructose in the intestine and sperm was clearly demonstrated (20). Modest to significant levels of GLUT5 mRNA and/or protein have now been demonstrated in kidney, fat, skeletal muscle, and brain $(55,65,66,76,81,91,101,135)$.

Paralleling the increasing concern about the role of fructose in various diseases, the number of studies on GLUT5 has increased dramatically in the last three years $(\sim 70$ studies from 2004 to 2007). Here, we review the evidence demonstrating the presence of GLUT5 in an increasing variety of organs and tissues and then describe its regulation under physiological and pathophysiological conditions.

\section{Physiology and Function}

Small intestine. The small intestine regulates fructose absorption from dietary sources and, therefore, the availability of fructose to other tissues. It is also the organ system expressing the greatest amount of GLUT5 in human $(13,20,47,79,81)$, rat $(24,35-38,45,72,75,84,108,112,113,139,140,147)$, mouse $(22,33,83,107)$, rabbit (109), chicken (60), and horse (104). In cattle, GLUT5 expression in the intestine is significantly lower than in skeletal muscle (159), probably because this species is a foregut fermenter, and it is possible that fructose-like cellulose and other carbohydrate products are fermented in the stomach and little sugar reaches the intestinal lumen.

After apical transport mediated by GLUT5, fructose is transported across the basolateral membrane by GLUT2. Recent work by Kellett and Brot-Laroche (82) proposes that GLUT2 is also involved in the apical transport of fructose (see also $5,15,136)$. The $K_{\mathrm{m}}$ for fructose measured in oocytes expressing the human isoform of GLUT5 or in the brush border membrane vesicles from rat and human intestine ranges from 11 to $15 \mathrm{mM}(20,79,100)$. This $K_{\mathrm{m}}$ is therefore similar to daytime intestinal luminal fructose concentrations in rats fed dietary fructose, $\sim 26 \mathrm{mM}(75)$. The $V_{\max }$ for GLUT5 measured in brush border membrane vesicles from rat intestine is $\sim 200 \mathrm{pmol} / \mathrm{s}$ per milligram of protein (100). In rodents, cattle, and horses, the distribution of GLUT5 is greater in the proximal (duodenum and proximal jejunum) compared with the distal segments (distal jejunum and ileum) (104, 160). In addition to regional expression patterns, GLUT5 gene expression appears to be tightly regulated by developmental, nutritional, hormonal, and circadian influences. The mechanisms involved in these regulatory processes are detailed in the following paragraphs.

Developmental patterns. Under normal conditions, in the prenatal and suckling periods of rat, rabbit, and human development ( $<14$ days in rodents), intestinal GLUT5 mRNA levels and fructose transport rates are very low $(17,51)$ (Fig. 1).

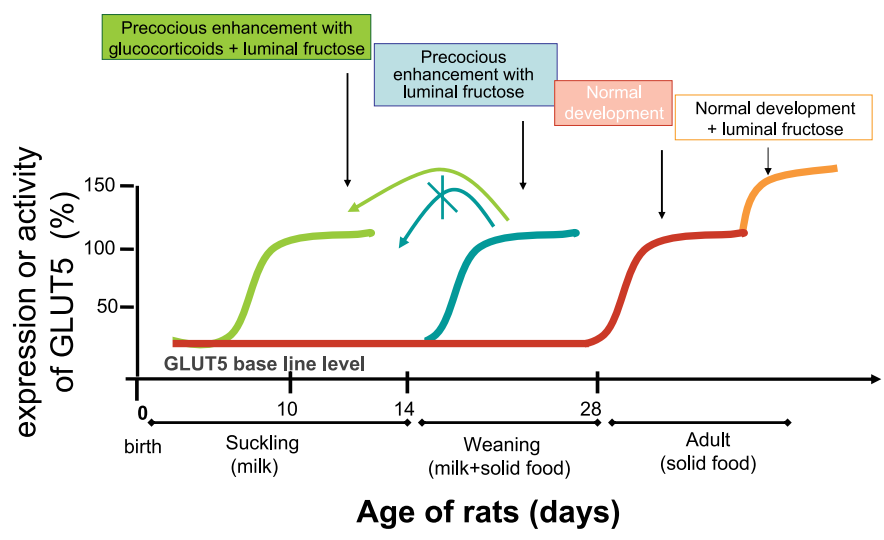

Fig. 1. Under normal conditions (red line), the intestinal fructose transporter GLUT5 is expressed at low baseline levels throughout suckling (0-14 days of age) and weaning (14-28 days) stages in neonatal rats. GLUT5 expression and activity increase normally after weaning has been completed and then can be enhanced by increases in consumption of dietary fructose (orange). Between 14 and 28 days old (blue), GLUT5 expression and activity are dramatically enhanced by precocious introduction of its substrate fructose into the intestinal lumen. GLUT5 cannot be enhanced by luminal fructose in rats $<14$ days old unless the gut is primed with dexamethasone (green).

Consumption of honey and fruit juice containing much fructose elicit marked increases in breath hydrogen (a marker of carbohydrate malabsorption) in children less than $1 \mathrm{yr}$ of age, but not in those 2 or more yr old, suggesting fructose-induced intestinal malabsorption in very young humans possibly expressing low GLUT5 levels (116). Fructose malabsorption in 5-mo-old infants is associated with infantile colic (46) and increases their energy requirements (150). In rats, baseline GLUT5 expression and activity remain low $(51,75)$ throughout postnatal development until the weaning stage (Fig. 1) and then increase only after completion of weaning when solid foods are consumed. The increase in activity at 28 days of age is thought to be hardwired (148) and may not require the presence of luminal fructose. This increase in GLUT5 expression and activity can be advanced developmentally in younger, weaning pups. Between 14 and 28 days of age, GLUT5 is dramatically stimulated by early introduction of dietary fructose or by gavage feeding fructose solutions into the gastric lumen $(35,42,45,75,112,139)$. At this age range, the nutritional regulation of GLUT5 by fructose is clearly genomic (75) and requires the presence of fructose in intestinal lumen (140). GLUT5 response to luminal fructose occurs rapidly as the mRNA abundance in all enterocytes lining the villus increases simultaneously within $4 \mathrm{~h}$ (74). In contrast to GLUT5, both intestinal GLUT2 and SGLT1 (the $\mathrm{Na}^{+}$-dependent glucose transporter) are expressed at high levels throughout development, even in the prenatal stage of mammals (17). From the prenatal to the weaning stages, rat SGLT1 does not seem to be regulated by sugars (139), whereas rat GLUT2 appears to be regulated by luminal and systemic glucose or fructose (36).

Role of glucocorticoid and thyroid hormones. In suckling rats younger than 14 days, gavage feeding or perfusion in vivo of fructose has no effect on the already low levels of GLUT5 expression and activity (Fig. 1) (38, 45, 74). This is understandable since milk is fructose free and there is no luminal signal that can stimulate GLUT5. However, GLUT5 in weaning rats ( $>14$ days old) with no access to solid food, or even 
those with access to fructose-free pellets, can be enhanced by fructose. What developmental factors control the dramatic difference in GLUT5 regulation between suckling and weaning stages? Cui et al. (38) and Douard et al. (45) used microarray approaches to identify in vivo intestinal regulatory genes that modulate fructose sensitivity by tracking changes in expression as a function of age and of perfusion solution. When the microarray results revealed that a significant number of ageand fructose-responsive genes were modulated by glucocorticoids, they hypothesized that corticosteroids play a major role in regulating intestinal GLUT5. By priming the gut with dexamethasone (a glucocorticoid analog), fructose was suddenly able to markedly stimulate GLUT5 even in suckling pups younger than 14 days (45). Dexamethasone also has similar stimulatory effects on the development of another intestinal membrane protein, sucrase-isomaltase, in similar-age pups, except that dexamethasone can directly upregulate sucraseisomaltase without its substrate sucrose (2).

The glucocorticoid receptor, which binds dexamethasone, may be one of the transcription factors involved in the glucocorticoid-mediated enhancement of GLUT5 by fructose (44). Another candidate transcription factor discovered by microarray as significantly and simultaneously fructose and dexamethasone responsive is karyopherin- $\alpha 2$ (45), a nuclear importin known to be involved in the trafficking of nuclear factors stimulating the transcription of sugar-responsive genes (23). The expression of karyopherin- $\alpha 2$ is stimulated by fructose at 20 days, an age when fructose can stimulate GLUT5, but not at 10 days, when fructose alone does not stimulate GLUT5 (45).

In older pups, $\sim 20-28$ days of age, glucocorticoids may no longer be involved in the fructose stimulation of GLUT5, since adrenalectomy of pups at 10 days of age does not prevent dietary fructose from enhancing GLUT5 expression (112). However, in this experiment, adrenalectomized pups received aldosterone every day to prevent salt wasting. Because aldosterone and corticosterone can both bind the glucocorticoid receptor with high affinity, this receptor may have mediated the effect of aldosterone on GLUT5 in the presence of fructose and confounded the effect of adrenalectomy on GLUT5 development.

The role of thyroid hormones, known to mediate the development of hydrolytic enzymes in the intestine, in the developmental regulation of GLUT5 has also been examined. Ltriiodothyronine enhances GLUT5 expression in Caco2 cells $(102,110,111)$. In fact, thyroid hormone response elements were identified in the $-338 /-272$ bp promoter region of GLUT5 $(102,111)$. However, the role of thyroid hormones in GLUT5 regulation so clearly demonstrated in cell culture may not be physiological because in vivo studies suggest that thyroxine does not regulate GLUT5. In normal pups, thyroxine concentrations increase significantly during the transition from suckling to weaning, and thyroxine may therefore be an ideal regulator of GLUT5 development (70). However, in weaning pups made hypothyroid from birth, dietary fructose can still enhance intestinal fructose uptake and GLUT5 mRNA expression even though thyroxine levels in the serum are very low (113).

Diurnal rhythm. In adult rats, GLUT5 mRNA and protein expression follow a distinct diurnal rhythm not found in neonatal rats (140). The rhythm occurs independent of food and fructose intake $(34,146)$, which in rats occur mostly and naturally at night (52). This diurnal rhythm consists of an anticipatory fourfold induction of intestinal GLUT5 mRNA and protein expression occurring 3-4 h before the onset of peak feeding. Thus, GLUT5 can be regulated by factors not associated with feeding or with changes in luminal fructose concentrations. The same diurnal rhythm was also observed for intestinal GLUT2 $(34,146)$. Diurnal regulation of GLUT5, like fructose regulation of GLUT5 in weaning rats, seems modulated by paracrine and endocrine signals in the intestine, because diurnal variation of GLUT5 expression is independent of the vagus nerve. In contrast, GLUT2 diurnal expression is controlled by vagal signals (146).

Kidney. After the small intestine, the kidney expresses the most GLUT5 in human, rat, and rabbit (4, 20, 28, 40, 81, 109, 126). GLUT5 mRNA is abundant in the cytosol, and protein is present in the apical plasma membrane of S3 proximal tubule cells $(28,145)$, where GLUT5 can potentially recapture fructose lost from glomerular filtration. Renal GLUT5 of rats has a $V_{\max }$ of $106 \mathrm{pmol} / \mathrm{s}$ per milligram of protein and a $K_{\mathrm{m}}$ of 12.6 $\mathrm{mM}$, values relatively similar to those in the small intestine (101). The $K_{\mathrm{m}}$, however, seems much higher than physiological fructose concentrations in the blood $(\sim 0.008-0.03 \mathrm{mM})$ and, presumably, glomerular filtrate. Fructose concentration in the urine of normal nondiabetic humans is $0.035 \mathrm{mM}$ (personal communication, T. Kawasaki). Differences in fructose concentration between filtrate and intracellular compartment will determine the direction of fructose flux mediated by GLUT5. GLUT2 is also in the basolateral membrane of proximal tubular cells, and the role of these two relatively low-affinity GLUTs in renal fructose transport, in light of relatively low, apparently similar fructose concentrations in the blood and urine, needs to be elucidated. The transcript size and molecular weight of the protein are similar to those determined for GLUT5 in the intestine (33), in accord with the resemblance in kinetic features of this transport system from the two organs. Moreover, during the prenatal period, the levels of renal GLUT5 mRNA and protein are low but then rapidly increase during weaning when its expression is also inducible by the fructose diet $(19,126)$, suggesting similar mechanisms of developmental regulation as those in the small intestine.

Testes and sperm. GLUT5 has consistently been found in the spermatozoa of many species: human $(3,20)$, mouse $(3,33)$, rat (3), bull (3), pig (133, 134), and dog (127). Even if its role in sperm metabolism remains uncertain, it may confer to the spermatozoa the ability to use fructose as an energy source or as an activator of the fertilization process $(3,127)$. In humans, GLUT5 is expressed only in mature spermatids, suggesting a selective upregulation of GLUT5 expression during germ cell development, from immature spermatogonia expressing low levels of GLUT5 through to elongated spermatids expressing high levels of GLUT5 $(3,20)$.

Testicular GLUT5 levels are also influenced by age as are those in the small intestine. Interestingly, changes in GLUT5 expression in the whole testis as a function of ontogenetic development parallels changes in GLUT5 expression as a function of spermatogenetic development. Testicular GLUT5 expression increases threefold in 6-wk-old adults compared with that in 1-wk-old prepubertal mice (33). This implies a reproductive function for fructose and suggests that, even in a tissue that does not deal with or perceive the diet change at 
weaning, an intrinsic factor with wide-ranging effects seems to be responsible for the developmental regulation of GLUT5.

The pubertal timing for the increase in GLUT5 expression in the testis reinforces the postulated relationship between steroid hormones and GLUT5 as previously described in the small intestine. The total transcript size of testicular GLUT5 is $2.8 \mathrm{~kb}$ and is significantly larger than the $2.1 \mathrm{~kb}$ size of intestinal and renal GLUT5 (33). The difference in transcript size may result from the existence of two distinct promoters, one type controlling GLUT5 transcription in somatic cells like intestinal epithelia and another type controlling transcription in germ cells, where GLUT5 contains an additional exon (33). The GLUT5 promoter in the intestine/kidney contains binding sites for the caudal homeobox gene (CdxA, a transcriptional factor involved in development of gastrointestinal tissues) (33). In addition to CdxA, the GLUT5 promoter in the testis also contains binding sites for the sex-determining region of $\mathrm{Y}$ (SRY, a transcriptional factor essential for the development of the testis), whose influence prevails over or supplements that of CdxA. These findings show how differences in promoter regions or in promoter activity may be responsible for the tissue-selective expression of GLUT5.

Musclelfat tissue. GLUT5 is expressed in skeletal muscle of human $(14,40,41,66,71,81,125,137,143,144)$, rat (40), and mouse (131). In fact, GLUT5 is, along with GLUT4 and GLUT12, one of the more significantly expressed GLUTs in human skeletal muscle compared with the other members of the GLUT family (144). However, GLUT5 mRNA and protein levels in skeletal muscle are low compared with those of the intestine in humans (81) and rats (40). Adipocytes of rats (65, 91) and humans (137) also express GLUT5, but expression seems less compared with that of the small intestine (81). GLUT5 expression is strictly confined to the plasma membrane of adipocytes and to the sarcolemma of skeletal muscle where it is responsible for facilitating fructose uptake from the blood into these tissues $(40,65,137)$. Since GLUT5 is facilitative and extracellular fructose concentration seems quite low (probably $69,161)$. In human adipocytes, a recent study demonstrated, hypoxia increases GLUT5 expression (9-fold) (155). Because hypoxia becomes more common during the progression of obesity, it can be one of the factors leading to increases in GLUT5 expression in adipocytes of young obese $f a / f a$ rats $(91)$.

In contrast to the intestine and kidney but like the testis, GLUT5 expression is not substrate dependent in muscle (40) but may be modulated by hormones. Insulin is capable of increasing the abundance and functional activity of GLUT5 in skeletal muscle cells, and the insulin effect is most likely mediated via activation of the GLUT5 promoter (66). The contribution of skeletal muscles and of adipocytes in the clearance from the blood and in metabolism of fructose is minor compared with that of the liver and the kidney.

Brain. Glucose is the principal substrate used by and is considered sufficient for the metabolic needs of the brain (142), so there is no requirement for additional energy sources. However, GLUT5 has been identified in different cell types such as human microglia (122), cerebellar Purkinje cells in human fetus (117), mouse cerebellum (55), human blood-brain barrier (98), and rat hippocampus (138). Because the GLUT5 transporter is commonly found in tissues that metabolize fructose (20), these brain cells may be capable of utilizing fructose as an energy substrate. However, the utility of fructose and function of GLUT5 remains uncertain in the brain. Since it is unlikely that the brain secretes fructose, the presence of GLUT5 in the blood-brain barrier indicates that fructose enters the brain, but radioalabeled fructose injected into rat arteries resulted in minimal accumulation of radio-labeled fructose in the brain, suggesting insignificant transport across the blood brain barrier (119) that is likely mediated by GLUT1. GLUT1 typically transports glucose across the blood brain barrier but has a very low affinity for fructose (39). In contrast to the finding that fructose does not enter the brain, a modest and transient upregulation of GLUT5 mRNA and protein levels in the brain has been demonstrated in rats consuming a high fructose diet (138) and following schemia (151). This suggests that fructose enters the brain because it is a potent and specific stimulator of GLUT5 transcription (51). Consistent with the controversial nature of this subject, a more recent study found that high fructose diets do not upregulate GLUT5 in the brain (106). Hence, the physiological role of GLUT5 and the effect of high-fructose diets in the brain still need to be investigated.

\section{Regulation of Intestinal GLUT5 by Its Own Substrate}

Regulation in vivo. Here, we will focus primarily on the intestinal regulation of GLUT5 in adults or weaning pups older than 14 days in which GLUT5 responds to luminal fructose. GLUT5 expression and function in weaning and postweaning rats can be enhanced markedly in vivo by consumption of high-fructose diets (42), gavage-feeding of fructose solutions (74), perfusion in vivo of the intestine with fructose (75), or incubation in vitro of isolated everted intestines in fructose solutions (85). Intestinal GLUT5 is therefore remarkably responsive to its substrate fructose. The response of GLUT5 is quite specific, as SGLT1 or GLUT2 expression is similar among fructose, glucose, and nonmetabolizable glucose analogs. Fructose metabolism, partial or total, may be a key factor in the regulatory process because of the modest effect of the nonmetabolizable fructose analog 3-O-methylfructose on GLUT5 upregulation in 20-day-old rats (75). Fructose is supposedly metabolized via either of two pathways, the fructose 1-phosphate and/or the fructose 6-phosphate pathway. Although the fructose 1-phosphate pathway using fructokinase and aldolase B seems to be prominent in the liver, it is not clear whether intestinal cells are capable of fructose metabolism and, if they are, which of the two pathways would prevail $(49,103)$.

Along with GLUT5, the mRNA expression of key gluconeogenic enzymes, glucose-6-phosphatase (G-6-Pase) and fructose-1,6-bisphosphatase (FBPase), increased significantly in fructose-perfused intestines, suggesting a link between gluconeogenesis on the one hand and fructose transport as well as intracellular fructose on the other (38). However, only the inhibition of FBPase activity using vanadate prevents the fructose-induced increase in GLUT5 mRNA expression and fructose uptake (84). FBPase activity is indirectly regulated by cAMP, which increases in vivo in the intestinal mucosa (35) or in vitro in Caco2 cells (94) exposed to fructose compared with those exposed to glucose. It had been demonstrated in vivo that cAMP modulates fructose transport induced by fructose without affecting GLUT5 mRNA abundance (35), whereas in vitro, cAMP affects GLUT5 mRNA expression levels (62). The reasons for these different effects of cAMP on the transcrip- 
tional and posttranscriptional regulation of GLUT5 by fructose remain unknown and may underlie the difference between in vitro and in vivo models. In fructose-perfused rats, the phosphatidylinositol 3-kinase/protein kinase B system (PI 3-kinase/ $\mathrm{Akt}$ ) also mediates the fructose-induced increase in fructose uptake but still has no effect on GLUT5 transcription (37). The signaling pathways in vivo related to the dramatic and specific fructose-induced increase in GLUT5 mRNA and activity remain to be elucidated, although several fructose-responsive genes identified from microarray comparisons of fructose- and glucose-perfused intestines suggest that 1) intracellular phosphate metabolism or transport, 2) several regulatory genes in the gluconeogenic pathway, and 3) alterations in ATP/ADP levels, may be involved (38).

Regulation in vitro in Caco2 cells. The molecular regulation of GLUT5 in the intestine has also been studied using mostly $\mathrm{Caco} 2$ cells as a model. Among the numerous clones of $\mathrm{Caco} 2$, GLUT5 is expressed endogenously only in those clones exhibiting low rates of glucose consumption (Caco2-PD7, -TB10, -TC7, -TF3, or -TG6) and only in those cells that are differentiated (94). It is not clear why these clones have low rates of glucose metabolism, but endogenous expression of GLUT5 suggests that they may be attempting to obtain additional sources of sugars. Interestingly, by use if glucokinase activity as an indicator of the rate of glucose metabolism, the intestine can be categorized more like a low-glucose-metabolizing tissue compared with the liver, brain, or adipose tissue in rats fed a carbohydrate diet (1). Although glucose under in vivo conditions does not alter GLUT5 mRNA and protein levels in enterocytes, both glucose and fructose are potent activators of GLUT5 in Caco 2 cells $(93,94,102,105)$. Hence, under most conditions, GLUT5 regulation in Caco2 cells does not distinguish between glucose and fructose. Only if postconfluent cells are grown in culture media containing dialyzed fetal bovine serum and only in Caco2/PD7 or Caco2/TC7 clones can fructose modestly induce GLUT5 expression to a greater extent than glucose (105).

Because fructose, compared with glucose, does not increase the activity of the human GLUT5 promoter in vitro, the modest fructose-induced increase of GLUT5 mRNA abundance in Caco 2 cells appears to result from increased mRNA stability (62). Since cAMP is involved in GLUT5 regulation in $\mathrm{Caco} 2$ cells $(93,94,105)$, increased mRNA stability may result from an inhibitory effect of cAMP on the formation of a complex between the GLUT5 3' UTR area and PABP (polyadenylatebinding protein)-interacting protein (Paip2). PABP proteins are found in all eukaryotes and are implicated primarily in mRNA maturation, export, and turnover (141). Specifically, Paip2, a partner of PABP, is involved in the destabilization of the transcripts, and inhibition of Paip2 enhances mRNA stability. Two cAMP potential response elements had been identified in the GLUT5 promoter and now localized to $-365 /-358$ and $-332 /-325$ regions (94). Interestingly, GLUT5 expression is also cAMP sensitive in primary cultures of rabbit proximal tubule cells (121).

\section{Pathology and GLUT5}

Diabetes/hyperinsulinemia. It is not clear whether diabetes alters serum fructose concentration. Serum fructose concentration and urinary fructose excretion increased markedly in diabetic
Japanese patients (80). On the other hand, serum fructose concentrations were similar among healthy Finnish volunteers and those with type 1 or 2 diabetes (124). What is clearer is that fructose may be profoundly involved in the development of metabolic syndromes important in the pathogenesis of diabetic complications $(56,63,86,120)$. Fructose is now the major sweetener in Western diets, and for a while was used in diabetes therapy because it did not result in acute hyperglycemia. GLUT5 is expressed in insulin-sensitive tissues like skeletal muscle and adipocytes of humans and rodents and may participate in the management of glycemia involving insulin. Despite the importance of dietary fructose in the development of diabetes, and that of GLUT5 in fructose transport, very few studies have investigated the link between diabetes and GLUT5 in these insulin-sensitive organ systems. The few studies that did so found interesting but inconsistent correlations between this transporter and diabetes, with inconsistencies arising from the fact that although GLUT5 may be affected by diabetes, GLUT5 is also particularly affected by levels of dietary fructose that may vary markedly among diabetes patients.

Patients with type 2 diabetes exhibited dramatic increases in GLUT5 mRNA and protein abundance in skeletal muscle (143). These increases were specific, because expression of GLUT1, GLUT3, GLUT4, GLUT8, GLUT11, and GLUT12 did not change with diabetes and could be reversed if diabetic patients were treated for $8 \mathrm{wk}$ with pioglitazone, a drug enhancing insulin action.

Several studies have also linked GLUT5 expression in fat tissue of rodent models with diabetes or with diabetic complications. In rats with streptozotocin-induced diabetes, there was a dramatic, insulin-insensitive, glycemia-regulated decrease in levels of GLUT5 mRNA and in rates of fructose uptake in adipose cells (65). Type 2 diabetes may have different effects on GLUT5, and those effects may be age or insulin dependent. GLUT5 protein abundance and activity increased two- to fourfold in young obese $\mathrm{fa} / \mathrm{fa}$ rats that were normoglycemic and hyperinsulinemic compared with lean controls. When insulin resistance (hyperinsulinemia and hyperglycemia) became established in aged obese $\mathrm{fa} / \mathrm{fa}$ rats, GLUT5 protein and the rate of fructose uptake in adipocytes decreased 12-fold (91). These reductions in site density of adipocyte GLUT5 can contribute to increases in plasma fructose concentrations in diabetes. Because GLUT5 abundance and fructose transport in adipocytes are upregulated in highly insulin-responsive rats but are downregulated dramatically when these rats age and become insulin resistant, this suggests that changes in GLUT5 expression in adipocytes of type 2 diabetics are dependent on insulin sensitivity. However, the exact role of insulin needs further study.

In the same aged $f a / f a$ rats, there was no effect of insulin resistance on GLUT5 protein levels in the kidney (91), suggesting that the effect of insulin resistance on GLUT5 was primarily in adipocytes. However, two studies observed an increase of GLUT5 mRNA and protein levels in rat kidney after onset of streptozotocin-induced diabetes $(4,28)$. Streptozotocin-induced diabetes results in increases in levels of GLUT5 in the apical membrane of mesangeal cells in the glomerulus and of proximal convoluted tubular cells in the renal cortex. Changes in the levels of GLUT5 in the membrane of tubular cells may affect rates of fructose transport to/from the filtrate, depending on concentration gradi- 
ents. Increases in levels of renal GLUT5 may mediate the threefold increase in urinary fructose excretion observed in type 2 diabetic patients (80).

Diabetes also profoundly affects GLUT5 expression in the small intestine. Duodenal GLUT5 mRNA and protein levels increase three- to fourfold in type 2 diabetic subjects (47). Lowering hyperglycemia in certain patients reversed this intestinal upregulation of GLUT5, suggesting that blood glucose level or its consequences are involved in the GLUT5 regulation in the intestine of diabetic subjects (47). In contrast, in Zucker rats, considered a model of type 2 diabetes, the mRNA and protein levels of the intestinal sugar transporters SGLT1, GLUT5, and GLUT2 remained the same as those of lean controls (31). These differences may arise from species differences or from the different composition of diets consumed by control and diabetic patients in the human study. Interestingly, treating the diabetic rats with troglitazone (another drug enhancing insulin action) specifically downregulates GLUT5 protein levels, consistent with previous observations (143).

In streptozotocin-induced type 1 diabetes, findings on intestine are also contradictory. In streptozotocin-diabetic rats, dramatic increases in levels of GLUT5 mRNA, cytosolic protein, and brush border protein were demonstrated in the jejunum and ileum $(18,32)$. Diabetes also increased intestinal size and caused a premature expression of hexose transporters by enterocytes along the crypt-villus axis, thereby causing a cumulative increase in enterocyte transporter protein during maturation. GLUT5 protein levels increased in parallel with a diminution of GLUT5 activity (32), suggesting less fructose transported per GLUT5. Unfortunately, in the same model of type 1 diabetic rats, another study observed a diabetes-induced reduction in intestinal GLUT5 expression (108). In summary, the regulation of intestinal GLUT5 in diabetic subjects seems to be complex, and no clear picture has emerged due to contradictory findings. This multifaceted regulation also reflects the complexity of diabetes-induced metabolic changes (e.g., hyperinsulinemia, hyperglycemia, insulin-resistance, obesity, inflammation) that can affect GLUT5 expression.

Arterial hypertension and obesity. Metabolic disorders like impairments in glucose metabolism and insulin resistance have also been reported in humans and mammals exhibiting arterial hypertension. In the ileum of spontaneously hypertensive (SHR) rats, the capacity to absorb fructose was reduced and levels of GLUT5 mRNA and protein decreased, suggesting a transcriptional downregulation of GLUT5 in the intestine of these rats (100). Levels of GLUT5 protein in renal brush border membrane vesicles of hypertensive rats compared with those from normotensive rats also decreased with hypertension (101). It is interesting to note that there exists another animal model for hypertension: young rats fed high levels of fructose. These young rats increase intestinal GLUT5 expression and then eventually develop glucose intolerance and high blood pressure (10).

The mechanism by which dietary fructose induces hypertension is being investigated. In rodents, fructose, unlike other sugars, induces hyperuricemia $(115,132)$ which is a major risk factor for hypertension (50). Recent clinical studies using patient data from the Third National Health and Nutrition Examination Survey confirm the link not only between hyperuricemia and hypertension in particular but also between serum concentrations of uric acid and the prevalence of metabolic syndrome in general $(29,53)$. In turn, consumption of sugarsweetened soft drinks is substantially correlated with increasing levels of serum uric acid and frequency of hyperuricemia (30). This increase in levels of blood uric acid can result from fructose-induced reduction in the renal excretion of uric acid and from the stimulation of nucleotide catabolism (67). However, little else is known about GLUT5 regulation and its physiological significance in fructose induced hypertension in animal models or humans.

Intestinal inflammatory and infectious diseases. Inflammatory or infectious conditions also lead to adaptive changes in intestinal absorptive function, including fructose transport. The link between inflammation or infection and fructose has been poorly explored, maybe because no inherited disorders of intestinal fructose transport have yet been reported. Isolated fructose malabsorption is rare and is not linked to protein-altering mutations in GLUT5, and the inheritance pattern is unknown (153). As a consequence, there are few studies on GLUT5 expression and function under pathological conditions in the intestine. In general, GLUT5 expression and activity decrease in inflammatory diseases. A patient with Helicobacter pylori infection exhibited a decrease in intestinal GLUT5 expression (87). In rats, 2-8 days after iodoacetamide-induced colitis, GLUT5 protein and mRNA levels decreased in noninflamed small intestine, thereby paralleling the time course of inflammation manifested in the large intestine and suggesting that GLUT5 in noninflamed tissues may be sensitive to inflammation inducers or to inflammatory signals in the blood (77). In the case of sepsis induced by lipopolysaccharide (LPS) or tumor necrosis factor- $\alpha$ (TNF- $\alpha$ ) in rabbit, fructose absorption also decreased in the jejunum $(57,59)$. When injected intravenously, LPS, which is a component of the membrane of gram-negative bacteria, stimulates cytokine (including TNF- $\alpha$ ) and glucocorticoid production. The decrease in rate of fructose absorption can be prevented by an inhibitor of TNF- $\alpha$ and can be explained mostly by decreases in GLUT5 protein levels in the enterocytes, indicating that the effect of inflammatory factors on GLUT5 is mainly specific. LPS treatment decreased GLUT5 levels by proteasome-dependent degradation. The regulatory mechanism underlying the inhibition of fructose absorption by LPS and TNF- $\alpha$ may involve cross talk among various protein kinase signaling pathways because specific inhibitors of PKC, PKA, and MAP kinases, p38 MAPK, JNK, and MEK1/2, protected fructose uptake from adverse LPS effects (58).

The role of bacteria and the adaptive immune responses it generates also seem to affect GLUT5 expression. Under nonpathological states but in the absence of both passive and adaptive immunity, a dramatic increase in expression of GLUT5 is observed in the proximal small intestine of 18-, 21-, and 25-day-old rats (73). This increased expression of GLUT5 in the immunodeficient host could be an adaptive response limiting the nutrients available for intestinal microflora in the more distal regions of the gut and indicate that when the immune system is compromised GLUT5 expression is upregulated.

GLUT5 is also found in immune cells like the mature macrophages of peripheral organs $(54,95)$ and in the microglia of the brain $(26,128,135,151)$. When human monocytes differentiate into macrophages, differentiation is accompanied by marked changes in intracellular location of GLUT5 and by dramatic increases in GLUT5 mRNA levels and protein abundance and in fructose uptake rate $(54,95)$. 
Breast cancer. GLUT5 mRNA and protein expression are affected by the development of tumors in certain organ systems. This surprising finding is not only consistent among different organ systems and cell types but also seems independent of associated metabolic or inflammatory diseases. In general, oncogene-transformed cells that portray cancerous characteristics will also exhibit an increase in glucose transport by overexpressing specifically sugar transporters like GLUT1 in breast, colorectal, lung, and ovarian carcinoma $(21,64,118$, 156), GLUT12 in breast cancer (129), or GLUT3 in lung, ovarian, and gastric cancers (157). This increase in glucose transport and metabolism may reflect a requirement by these rapidly growing cells for more sources of energy (27). Although GLUT5 is poorly expressed in normal mammary epithelial cells, the breast carcinoma cell lines MCF-7 and MDAMB-231 possess high amounts of GLUT5 mRNA and protein and exhibit high rates of fructose transport (158). This finding from an earlier study was later on confirmed a number of times in later studies. In fact, GLUT5 knockdown by antisense oligonucleotide decreases rates of fructose uptake, thereby inhibiting the proliferation and the growth of MCF-7 and MDA-MB-231 cells, which are, respectively, models of earlyand late-stage breast cancer (25). A large-scale screening of the GLUT family of transporters in malignant vs. normal human tissues and cells showed that GLUT5 was highly overexpressed in $27 \%$ of cancerous tissues tested, including tumors in brain, breast, colon, liver, lung, testis, and uterus (61). In situ RT-PCR and ultrastructural immunohistochemistry confirmed GLUT5 expression in breast cancer. In contrast, GLUT6 and -9 are clearly not overexpressed in human cancer of various tissues, whereas GLUT1 is expressed in cancers of a wide range of tissues but expression in each tissue is modest. The extensive expression of the glucose/fructose transporter GLUT2, and the fact that in most of the tumor cells overexpressing GLUT5 the rate of fructose uptake is exacerbated, indicate that fructose may be a preferred substrate providing energy required for the growth and proliferation of tumor cells $(61,89)$. This increase of GLUT5 could indicate preferential utilization of fructose by cancer cells. However, the link between fructose and tumor cell growth remains unclear. Interestingly, it was observed over 50 years ago that cancer cells maintain a high rate of glycolysis even in the presence of oxygen, a phenomenon called the Warburg effect $(7,123,152)$. One of the major regulatory steps in glycolysis involves conversion of fructose 6-phosphate to fructose-1,6-bisphosphate by phosphofructokinase-1 (PFK-1). The activity of PFK-1 is allosterically controlled by fructose-2,6-bisphosphate, the product of the enzymatic activity of a dual kinase/phosphatase family of enzymes (PFKFB1-4) that is also increased in a significant number of tumor types (6). Fructose is known to stimulate the intestinal expression of PFKFB1 (38), but it is not known whether fructose leads to increased levels of fructose 2,6-bisphosphate. However, it is clear that the rate of glycolysis can be stimulated by fructose because its entrance into glycolysis skips the two main regulatory enzymes (glucokinase and PFK-1) (67). Either the presence of GLUT5 leads to a greater use of fructose by neoplastic cells, or increased usage of fructose leads to a higher abundance of GLUT5. Clearly, the role of fructose in enhanced glycolysis observed in cancer cells requires further study.

\section{Future Research}

GLUT5 is found in many tissues, and its expression and activity are clearly regulated under normal and are altered under pathological conditions (Fig. 2). The increasing importance of fructose in human nutrition and disease calls for additional studies that hopefully will increase our understanding of the role of the fructose transporter GLUT5 in health and disease.

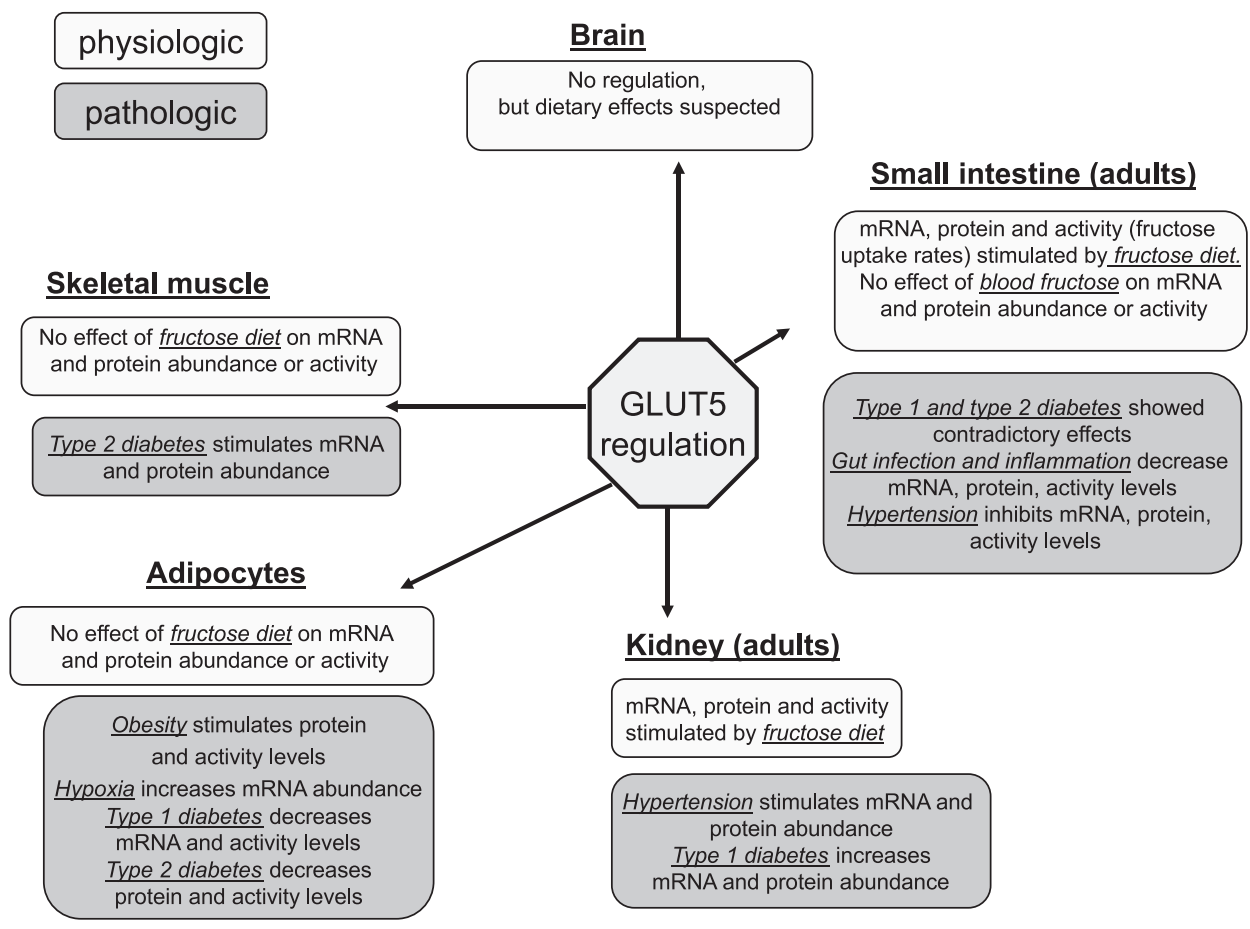

Fig. 2. Multiple regulatory parameters of GLUT5 expression and protein abundance and activity under physiological (light shading) and pathological (darker shading) conditions in small intestine, kidney, adipocytes, skeletal muscle, and brain. 
Estimates of fructose concentrations in plasma, urine, and cerebrospinal and intracellular fluids, as well as kinetic properties of GLUT5 in other tissues, are needed to better understand the role of GLUT5 in fructose metabolism and the role of fructose in GLUT5 regulation.

GLUT5 is expressed in only a limited number of tissues seemingly capable of or preferentially metabolizing fructose, and there exist two major categories of transcriptional and/or posttranscriptional regulation of GLUT5. In the apical membrane of polarized cells (e.g., enterocytes and renal cells), GLUT5 is acutely and specifically regulated by its own substrate, whereas in the other tissues, like adipocytes, fructose seems to have no acute effect. The signaling cascade regulating this specific and acute regulation in epithelial cells of GLUT5 by fructose is not known and can be compared with signals regulating substrate-independent modulation of GLUT5 in other tissues. The subcellular redistribution of GLUT5 following different stimuli also merits attention.

In Caco 2 cells and in highly proliferative cancer cells, GLUT5 expression is significant enough that it appears to be a good marker of malignancy or high proliferation rate. This suggests that cancerous cells lose the inhibitory factor(s) that blocks intensive GLUT5 expression in normal cells. The mechanisms underlying GLUT5 induction in cancer need to be identified.

Until now, the developmentally regulated biological factor(s) allowing luminal fructose to enhance GLUT5 expression after but not before 14 days of age has not been identified. Moreover, related factors that trigger diurnal rhythms of GLUT5 expression in adults are not known. The mechanisms underlying and the factors involved in the glucocorticoidallowed, fructose-induced regulation of GLUT5 in suckling rats need further study.

Information about ontogenetic development of human intestinal GLUT5 is needed to increase our understanding not only of the role fructose plays in intestinal fructose malabsorption but also of the correlation between fructose malabsorption and infant colic.

\section{ACKNOWLEDGMENTS}

We thank Drs. X. Cui, M. Dudley, E. David, J. Jiang, I. Monteiro, and R. Shu and all former students and collaborators for their contributions to our work on GLUT5. We also thank Dr. T. Kawasaki, Teikyo University School of Medicine, Japan, for providing unpublished data.

\section{GRANTS}

We are grateful for financial support from the National Science Foundation (IOS-0722365, IBN-0235011, IBN-9985808), the National Institutes of Health (R-DK-075617A), and the Foundation of UMDNJ.

\section{REFERENCES}

1. Abraham S, Borrebaek B, Chaikoff IL. Effect of dietary carbohydrate and glucokinase and mannokinase activities of various rat tissues. J Nutr 83: 273-288, 1964

2. Agbemafle BM, Oesterreicher TJ, Shaw CA, Henning SJ. Immediate early genes of glucocorticoid action on the developing intestine. Am J Physiol Gastrointest Liver Physiol 288: G897-G906, 2005.

3. Angulo C, Rauch MC, Droppelmann A, Reyes AM, Slebe JC, Delgado-Lopez F, Guaiquil VH, Vera JC, Concha II. Hexose transporter expression and function in mammalian spermatozoa: cellular localization and transport of hexoses and vitamin C. J Cell Biochem 71: 189-203, 1998.

4. Asada T, Ogawa T, Iwai M, Shimomura K, Kobayashi M. Recombinant insulin-like growth factor I normalizes expression of renal glucose transporters in diabetic rats. Am J Physiol Renal Physiol 273: F27-F37, 1997.
5. Baba R, Yamami M, Sakuma Y, Fujita M, Fujimoto S. Relationship between glucose transporter and changes in the absorptive system in small intestinal absorptive cells during the weaning process. Med Mol Morphol 38: 47-53, 2005.

6. Bando H, Atsumi T, Nishio T, Niwa H, Mishima S, Shimizu C, Yoshioka N, Bucala R, Koike T. Phosphorylation of the 6-phosphofructo-2-kinase/fructose 2,6-bisphosphatase/PFKFB3 family of glycolytic regulators in human cancer. Clin Cancer Res 11: 5784-5792, 2005.

7. Bartrons R, Caro J. Hypoxia, glucose metabolism and the Warburg's effect. J Bioenerg Biomembr 39: 223-229, 2007.

8. Basciano H, Federico L, Adeli K. Fructose, insulin resistance, and metabolic dyslipidemia. Nutr Metab (Lond) 2: 5, 2005.

9. Bell GI, Kayano T, Buse JB, Burant CF, Takeda J, Lin D, Fukumoto H, Seino S. Molecular biology of mammalian glucose transporters. Diabetes Care 13: 198-208, 1990.

10. Bell RC, Ryan EA, Finegood DT. Consequences of high dietary fructose in the islet-transplanted rat with suboptimal beta-cell mass. Am J Physiol Endocrinol Metab 270: E292-E298, 1996.

11. Bhosale SH, Rao MB, Deshpande VV. Molecular and industrial aspects of glucose isomerase. Microbiol Rev 60: 280-300, 1996.

12. Bizeau ME, Pagliassotti MJ. Hepatic adaptations to sucrose and fructose. Metabolism 54: 1189-1201, 2005.

13. Blakemore SJ, Aledo JC, James J, Campbell FC, Lucocq JM, Hundal HS. The GLUT5 hexose transporter is also localized to the basolateral membrane of the human jejunum. Biochem J 309 (Pt 1): 7-12, 1995.

14. Blakemore SJ, Rickhuss PK, Watt PW, Rennie MJ, Hundal HS. Effects of limb immobilization on cytochrome c oxidase activity and GLUT4 and GLUT5 protein expression in human skeletal muscle. Clin Sci (Lond) 91: 591-599, 1996.

15. Boudry G, Cheeseman CI, Perdue MH. Psychological stress impairs $\mathrm{Na}^{+}$-dependent glucose absorption and increases GLUT2 expression in the rat jejunal brush-border membrane. Am J Physiol Regul Integr Comp Physiol 292: R862-R867, 2007.

16. Bray GA. How bad is fructose? Am J Clin Nutr 86: 895-896, 2007.

17. Buddington RK, Diamond JM. Ontogenetic development of intestinal nutrient transporters. Annu Rev Physiol 51: 601-619, 1989.

18. Burant CF, Flink S, DePaoli AM, Chen J, Lee WS, Hediger MA, Buse JB, Chang EB. Small intestine hexose transport in experimental diabetes. Increased transporter mRNA and protein expression in enterocytes. J Clin Invest 93: 578-585, 1994.

19. Burant CF, Saxena M. Rapid reversible substrate regulation of fructose transporter expression in rat small intestine and kidney. Am J Physiol Gastrointest Liver Physiol 267: G71-G79, 1994.

20. Burant CF, Takeda J, Brot-Laroche E, Bell GI, Davidson NO. Fructose transporter in human spermatozoa and small intestine is GLUT5. J Biol Chem 267: 14523-14526, 1992.

21. Cantuaria G, Fagotti A, Ferrandina G, Magalhaes A, Nadji M, Angioli R, Penalver M, Mancuso S, Scambia G. GLUT-1 expression in ovarian carcinoma: association with survival and response to chemotherapy. Cancer 92: 1144-1150, 2001.

22. Casirola DM, Lan Y, Ferraris RP. Effects of changes in calorie intake on intestinal nutrient uptake and transporter mRNA levels in aged mice. J Gerontol A Biol Sci Med Sci 52: B300-B310, 1997.

23. Cassany A, Guillemain G, Klein C, Dalet V, Brot-Laroche $\mathbf{E}$, Leturque A. A karyopherin alpha2 nuclear transport pathway is regulated by glucose in hepatic and pancreatic cells. Traffic 5: 10-19, 2004.

24. Castello A, Guma A, Sevilla L, Furriols M, Testar X, Palacin M, Zorzano A. Regulation of GLUT5 gene expression in rat intestinal mucosa: regional distribution, circadian rhythm, perinatal development and effect of diabetes. Biochem J 309: 271-277, 1995.

25. Chan KK, Chan JY, Chung KK, Fung KP. Inhibition of cell proliferation in human breast tumor cells by antisense oligonucleotides against facilitative glucose transporter 5. J Cell Biochem 93: 1134-1142, 2004.

26. Cheepsunthorn P, Radov L, Menzies S, Reid J, Connor JR. Characterization of a novel brain-derived microglial cell line isolated from neonatal rat brain. Glia 35: 53-62, 2001.

27. Chesney J. 6-Phosphofructo-2-kinase/fructose-2,6-bisphosphatase and tumor cell glycolysis. Curr Opin Clin Nutr Metab Care 9: 535-539, 2006.

28. Chin E, Zamah AM, Landau D, Gronbcek H, Flyvbjerg A, LeRoith D, Bondy CA. Changes in facilitative glucose transporter messenger ribonucleic acid levels in the diabetic rat kidney. Endocrinology 138: 1267-1275, 1997. 
29. Choi HK, Ford ES. Prevalence of the metabolic syndrome in individuals with hyperuricemia. Am J Med 120: 442-447, 2007.

30. Choi JW, Ford ES, Gao X, Choi HK. Sugar-sweetened soft drinks, diet soft drinks, and serum uric acid level: the Third National Health and Nutrition Examination Survey. Arthritis Rheum 59: 109-116, 2008.

31. Corpe C, Sreenan S, Burant C. Effects of type-2 diabetes and troglitazone on the expression patterns of small intestinal sugar transporters and PPAR-gamma in the Zucker diabetic fatty rat. Digestion 63: 116123, 2001.

32. Corpe CP, Basaleh MM, Affleck J, Gould G, Jess TJ, Kellett GL. The regulation of GLUT5 and GLUT2 activity in the adaptation of intestinal brush-border fructose transport in diabetes. Pflügers Arch 432: 192-201, 1996.

33. Corpe CP, Bovelander FJ, Munoz CM, Hoekstra JH, Simpson IA, Kwon O, Levine M, Burant CF. Cloning and functional characterization of the mouse fructose transporter, GLUT5. Biochim Biophys Acta 1576: 191-197, 2002.

34. Corpe CP, Burant CF. Hexose transporter expression in rat small intestine: effect of diet on diurnal variations. Am J Physiol Gastrointest Liver Physiol 271: G211-G216, 1996.

35. Cui XL, Ananian C, Perez E, Strenger A, Beuve AV, Ferraris RP. Cyclic AMP stimulates fructose transport in neonatal rat small intestine. J Nutr 134: 1697-1703, 2004.

36. Cui XL, Jiang L, Ferraris RP. Regulation of rat intestinal GLUT2 mRNA abundance by luminal and systemic factors. Biochim Biophys Acta 1612: 178-185, 2003.

37. Cui XL, Schlesier AM, Fisher EL, Cerqueira C, Ferraris RP. Fructose-induced increases in neonatal rat intestinal fructose transport involve the PI3-kinase/Akt signaling pathway. Am J Physiol Gastrointest Liver Physiol 288: G1310-G1320, 2005.

38. Cui XL, Soteropoulos P, Tolias P, Ferraris RP. Fructose-responsive genes in the small intestine of neonatal rats. Physiol Genomics 18: 206-217, 2004.

39. Cunningham P, Afzal-Ahmed I, Naftalin RJ. Docking studies show that D-glucose and quercetin slide through the transporter GLUT1. J Biol Chem 281: 5797-5803, 2006.

40. Darakhshan F, Hajduch E, Kristiansen S, Richter EA, Hundal HS. Biochemical and functional characterization of the GLUT5 fructose transporter in rat skeletal muscle. Biochem J 336: 361-366, 1998.

41. Darakhshan F, Kristiansen S, Richter E, Hundal HS. GLUT5 and fructose transport in human skeletal muscle. Biochem Soc Trans 25: 473S, 1997

42. David ES, Cingari DS, Ferraris RP. Dietary induction of intestinal fructose absorption in weaning rats. Pediatr Res 37: 777-782, 1995.

43. Doege H, Bocianski A, Scheepers A, Axer H, Eckel J, Joost HG, Schurmann A. Characterization of human glucose transporter (GLUT) 11 (encoded by SLC2A11), a novel sugar-transport facilitator specifically expressed in heart and skeletal muscle. Biochem J 359: 443-449, 2001.

44. Douard V, Choi H, Ferraris RP. Overcoming developmental limitations to intestinal sugar transport: the role of glucocorticoids [on CDROM] (Abstract). FASEB J 21: \#931.937, 2007.

45. Douard V, Cui XL, Soteropoulos P, Ferraris RP. Dexamethasone sensitizes the neonatal intestine to fructose induction of intestinal fructose transporter (Slc2A5) function. Endocrinology 149: 409-423, 2008.

46. Duro D, Rising R, Cedillo M, Lifshitz F. Association between infantile colic and carbohydrate malabsorption from fruit juices in infancy. Pediatrics 109: 797-805, 2002.

47. Dyer J, Wood IS, Palejwala A, Ellis A, Shirazi-Beechey SP. Expression of monosaccharide transporters in intestine of diabetic humans. Am J Physiol Gastrointest Liver Physiol 282: G241-G248, 2002.

48. Elliott SS, Keim NL, Stern JS, Teff K, Havel PJ. Fructose, weight gain, and the insulin resistance syndrome. Am J Clin Nutr 76: 911-922, 2002.

49. Ellwood KC, Chatzidakis C, Failla ML. Fructose utilization by the human intestinal epithelial cell line, Caco-2. Proc Soc Exp Biol Med 202: 440-446, 1993.

50. Feig DI, Kang DH, Nakagawa T, Mazzali M, Johnson RJ. Uric acid and hypertension. Curr Hypertens Rep 8: 111-115, 2006.

51. Ferraris RP. Dietary and developmental regulation of intestinal sugar transport. Biochem J 360: 265-276, 2001

52. Ferraris RP, Yasharpour S, Lloyd KC, Mirzayan R, Diamond JM. Luminal glucose concentrations in the gut under normal conditions. Am J Physiol Gastrointest Liver Physiol 259: G822-G837, 1990.
53. Ford ES, Li C, Cook S, Choi HK. Serum concentrations of uric acid and the metabolic syndrome among US children and adolescents. Circulation 115: 2526-2532, 2007

54. Fu Y, Maianu L, Melbert BR, Garvey WT. Facilitative glucose transporter gene expression in human lymphocytes, monocytes, and macrophages: a role for GLUT isoforms 1, 3, and 5 in the immune response and foam cell formation. Blood Cells Mol Dis 32: 182-190, 2004.

55. Funari VA, Herrera VL, Freeman D, Tolan DR. Genes required for fructose metabolism are expressed in Purkinje cells in the cerebellum. Brain Res Mol Brain Res 142: 115-122, 2005.

56. Gaby AR. Adverse effects of dietary fructose. Altern Med Rev 10: 294-306, 2005

57. Garcia-Herrera J, Abad B, Rodriguez-Yoldi MJ. Effect of lipopolysaccharide on D-fructose transport across rabbit jejunum. Inflamm Res 52: 177-184, 2003

58. Garcia-Herrera J, Marca MC, Brot-Laroche E, Guillen N, Acin S, Navarro MA, Osada J, Rodriguez-Yoldi MJ. Protein kinases, TNF- $\alpha$ and proteasome contribute in the inhibition of fructose intestinal transport by sepsis in vivo. Am J Physiol Gastrointest Liver Physiol 294: G155G164, 2008.

59. Garcia-Herrera J, Navarro MA, Marca MC, de la Osada J, Rodriguez-Yoldi MJ. The effect of tumor necrosis factor-alpha on D-fructose intestinal transport in rabbits. Cytokine 25: 21-30, 2004.

60. Gilbert ER, Li H, Emmerson DA, Webb KE Jr, Wong EA. Developmental regulation of nutrient transporter and enzyme mRNA abundance in the small intestine of broilers. Poult Sci 86: 1739-1753, 2007.

61. Godoy A, Ulloa V, Rodriguez F, Reinicke K, Yanez AJ, Garcia Mde L, Medina RA, Carrasco M, Barberis S, Castro T, Martinez F, Koch X, Vera JC, Poblete MT, Figueroa CD, Peruzzo B, Perez F, Nualart F. Differential subcellular distribution of glucose transporters GLUT1-6 and GLUT9 in human cancer: ultrastructural localization of GLUT1 and GLUT5 in breast tumor tissues. J Cell Physiol 207: 614-627, 2006.

62. Gouyon F, Onesto C, Dalet V, Pages G, Leturque A, Brot-Laroche E. Fructose modulates GLUT5 mRNA stability in differentiated Caco-2 cells: role of cAMP-signalling pathway and PABP (polyadenylatedbinding protein)-interacting protein (Paip) 2. Biochem J 375: 167-174, 2003.

63. Gross LS, Li L, Ford ES, Liu S. Increased consumption of refined carbohydrates and the epidemic of type 2 diabetes in the United States: an ecologic assessment. Am J Clin Nutr 79: 774-779, 2004.

64. Haber RS, Rathan A, Weiser KR, Pritsker A, Itzkowitz SH, Bodian C, Slater G, Weiss A, Burstein DE. GLUT1 glucose transporter expression in colorectal carcinoma: a marker for poor prognosis. Cancer 83: $34-40,1998$.

65. Hajduch E, Darakhshan F, Hundal HS. Fructose uptake in rat adipocytes: GLUT5 expression and the effects of streptozotocin-induced diabetes. Diabetologia 41: 821-828, 1998.

66. Hajduch E, Litherland GJ, Turban S, Brot-Laroche E, Hundal HS. Insulin regulates the expression of the GLUT5 transporter in L6 skeletal muscle cells. FEBS Lett 549: 77-82, 2003.

67. Hallfrisch J. Metabolic effects of dietary fructose. FASEB J 4: 2652 2660, 1990.

68. Hanover LM, White JS. Manufacturing, composition, and applications of fructose. Am J Clin Nutr 58: 724S-732S, 1993.

69. Havel PJ. Dietary fructose: implications for dysregulation of energy homeostasis and lipid/carbohydrate metabolism. Nutr Rev 63: 133-157, 2005 .

70. Henning SJ. Postnatal development: coordination of feeding, digestion, and metabolism. Am J Physiol Gastrointest Liver Physiol 241: G199G214, 1981.

71. Hundal HS, Ahmed A, Guma A, Mitsumoto Y, Marette A, Rennie MJ, Klip A. Biochemical and immunocytochemical localization of the "GLUT5 glucose transporter" in human skeletal muscle. Biochem J 286: 339-343, 1992

72. Inukai K, Asano T, Katagiri H, Ishihara H, Anai M, Fukushima Y, Tsukuda K, Kikuchi M, Yazaki Y, Oka Y. Cloning and increased expression with fructose feeding of rat jejunal GLUT5. Endocrinology 133: 2009-2014, 1993

73. Jenkins SL, Wang J, Vazir M, Vela J, Sahagun O, Gabbay P, Hoang L, Diaz RL, Aranda R, Martin MG. Role of passive and adaptive immunity in influencing enterocyte-specific gene expression. Am J Physiol Gastrointest Liver Physiol 285: G714-G725, 2003. 
74. Jiang L, David ES, Espina N, Ferraris RP. GLUT-5 expression in neonatal rats: crypt-villus location and age-dependent regulation. Am J Physiol Gastrointest Liver Physiol 281: G666-G674, 2001.

75. Jiang L, Ferraris R. Developmental reprogramming of rat GLUT-5 requires de novo mRNA and protein synthesis. Am J Physiol Gastrointest Liver Physiol 280: G113-G120, 2001.

76. Joost HG, Thorens B. The extended GLUT-family of sugar/polyol transport facilitators: nomenclature, sequence characteristics, and potential function of its novel members (review). Mol Membr Biol 18: 247-256, 2001

77. Jurjus A, Barada K, Khoury N, Assef MD, Foltzer CJ, Reimund JM, Kedinger M. Morphological and biochemical alterations in the jejunum following iodoacetamide-induced colitis in rats. Can J Physiol Pharmacol 84: 1191-1203, 2006.

78. Kamari Y, Grossman E, Oron-Herman M, Peleg E, Shabtay Z, Shamiss A, Sharabi Y. Metabolic stress with a high carbohydrate diet increases adiponectin levels. Horm Metab Res 39: 384-388, 2007.

79. Kane S, Seatter MJ, Gould GW. Functional studies of human GLUT5: effect of $\mathrm{pH}$ on substrate selection and an analysis of substrate interactions. Biochem Biophys Res Commun 238: 503-505, 1997.

80. Kawasaki T, Akanuma H, Yamanouchi T. Increased fructose concentrations in blood and urine in patients with diabetes. Diabetes Care 25: 353-357, 2002

81. Kayano T, Burant CF, Fukumoto H, Gould GW, Fan YS, Eddy RL, Byers MG, Shows TB, Seino S, Bell GI. Human facilitative glucose transporters. Isolation, functional characterization, and gene localization of cDNAs encoding an isoform (GLUT5) expressed in small intestine, kidney, muscle, and adipose tissue and an unusual glucose transporter pseudogene-like sequence (GLUT6). J Biol Chem 265: 13276-13282, 1990.

82. Kellett GL, Brot-Laroche E. Apical GLUT2: a major pathway of intestinal sugar absorption. Diabetes 54: 3056-3062, 2005.

83. Kim HR, Park SW, Cho HJ, Chae KA, Sung JM, Kim JS, Landowski CP, Sun D, Abd El-Aty AM, Amidon GL, Shin HC. Comparative gene expression profiles of intestinal transporters in mice, rats and humans. Pharmacol Res 56: 224-236, 2007.

84. Kirchner S, Kwon E, Muduli A, Cerqueira C, Cui XL, Ferraris RP. Vanadate but not tungstate prevents the fructose-induced increase in GLUT5 expression and fructose uptake by neonatal rat intestine. $J$ Nutr 136: 2308-2313, 2006.

85. Kirchner S, Muduli A, Casirola D, Prum K, Douard V, Ferraris RP. Luminal fructose inhibits rat intestinal sodium-phosphate cotransporter gene expression and phosphate uptake. Am J Clin Nutr in press, 2008.

86. Le KA, Tappy L. Metabolic effects of fructose. Curr Opin Clin Nutr Metab Care 9: 469-475, 2006.

87. Lertanekawattana S, Wichatrong T, Chaisiri K, Uchikawa R, Arizono N. Expression of cytokines and monosaccharide transporters in the duodenal mucosa of patients with gastrointestinal symptoms in rural Thailand. Southeast Asian J Trop Med Public Health 36: 923-930, 2005.

88. Leturque A, Brot-Laroche E, Le Gall M, Stolarczyk E, Tobin V. The role of GLUT2 in dietary sugar handling. J Physiol Biochem 61: 529_ $537,2005$.

89. Levi J, Cheng Z, Gheysens O, Patel M, Chan CT, Wang Y, Namavari M, Gambhir SS. Fluorescent fructose derivatives for imaging breast cancer cells. Bioconjug Chem 18: 628-634, 2007.

90. Li Q, Manolescu A, Ritzel M, Yao S, Slugoski M, Young JD, Chen $\mathbf{X Z}$, Cheeseman CI. Cloning and functional characterization of the human GLUT7 isoform SLC2A7 from the small intestine. Am J Physiol Gastrointest Liver Physiol 287: G236-G242, 2004

91. Litherland GJ, Hajduch E, Gould GW, Hundal HS. Fructose transport and metabolism in adipose tissue of Zucker rats: diminished GLUT5 activity during obesity and insulin resistance. Mol Cell Biochem 261: 23-33, 2004.

92. Macdonald I, Keyser A, Pacy D. Some effects, in man, of varying the load of glucose, sucrose, fructose, or sorbitol on various metabolites in blood. Am J Clin Nutr 31: 1305-1311, 1978.

93. Mahraoui L, Rodolosse A, Barbat A, Dussaulx E, Zweibaum A, Rousset M, Brot-Laroche E. Presence and differential expression of SGLT1, GLUT1, GLUT2, GLUT3 and GLUT5 hexose-transporter mRNAs in Caco-2 cell clones in relation to cell growth and glucose consumption. Biochem J 298: 629-633, 1994.

94. Mahraoui L, Takeda J, Mesonero J, Chantret I, Dussaulx E, Bell GI, Brot-Laroche E. Regulation of expression of the human fructose transporter (GLUT5) by cyclic AMP. Biochem J 301: 169-175, 1994.
95. Malide D, Davies-Hill TM, Levine M, Simpson IA. Distinct localization of GLUT-1, -3 , and -5 in human monocyte-derived macrophages: effects of cell activation. Am J Physiol Endocrinol Metab 274: E516E526, 1998

96. Manolescu A, Salas-Burgos AM, Fischbarg J, Cheeseman CI. Identification of a hydrophobic residue as a key determinant of fructose transport by the facilitative hexose transporter SLC2A7 (GLUT7). J Biol Chem 280: 42978-42983, 2005.

97. Manolescu AR, Witkowska K, Kinnaird A, Cessford T, Cheeseman C. Facilitated hexose transporters: new perspectives on form and function. Physiology (Bethesda) 22: 234-240, 2007.

98. Mantych GJ, James DE, Devaskar SU. Jejunal/kidney glucose transporter isoform (Glut-5) is expressed in the human blood-brain barrier. Endocrinology 132: 35-40, 1993.

99. Marshall RO, Kooi ER. Enzymatic conversion of D-glucose to Dfructose. Science 125: 648-649, 1957.

100. Mate A, Barfull A, Hermosa AM, Planas JM, Vazquez CM. Regulation of D-fructose transporter GLUT5 in the ileum of spontaneously hypertensive rats. J Membr Biol 199: 173-179, 2004.

101. Mate A, de la Hermosa MA, Barfull A, Planas JM, Vazquez CM. Characterization of D-fructose transport by rat kidney brush-border membrane vesicles: changes in hypertensive rats. Cell Mol Life Sci 58: 1961-1967, 2001.

102. Matosin-Matekalo M, Mesonero JE, Laroche TJ, Lacasa M, BrotLaroche E. Glucose and thyroid hormone co-regulate the expression of the intestinal fructose transporter GLUT5. Biochem J 339: 233-239, 1999.

103. Mayes PA. Intermediary metabolism of fructose. Am J Clin Nutr 58: 754S-765S, 1993.

104. Merediz EF, Dyer J, Salmon KS, Shirazi-Beechey SP. Molecular characterisation of fructose transport in equine small intestine. Equine Vet $J$ 36: 532-538, 2004.

105. Mesonero J, Matosin M, Cambier D, Rodriguez-Yoldi MJ, BrotLaroche E. Sugar-dependent expression of the fructose transporter GLUT5 in Caco-2 cells. Biochem J 312: 757-762, 1995.

106. Messier C, Whately K, Liang J, Du L, Puissant D. The effects of a high-fat, high-fructose, and combination diet on learning, weight, and glucose regulation in C57BL/6 mice. Behav Brain Res 178: 139-145, 2007.

107. Miura T, Kako M, Ishihara E, Seino Y, Tanigawa K. Antidiabetic mechanism of Bakumondo-inshi. Biol Pharm Bull 22: 388-390, 1999.

108. Miyamoto K, Hase K, Taketani Y, Minami H, Oka T, Nakabou Y, Hagihira $\mathbf{H}$. Diabetes and glucose transporter gene expression in rat small intestine. Biochem Biophys Res Commun 181: 1110-1117, 1991.

109. Miyamoto K, Tatsumi S, Morimoto A, Minami H, Yamamoto H, Sone K, Taketani Y, Nakabou Y, Oka T, Takeda E. Characterization of the rabbit intestinal fructose transporter (GLUT5). Biochem J 303: 877-883, 1994

110. Mochizuki K, Sakaguchi N, Goda T. Triiodothyronine (T3) and fructose coordinately enhance expression of the GLUT5 gene in the small intestine of rats during weaning period. Biosci Biotechnol Biochem 71: 1345-1347, 2007

111. Mochizuki K, Sakaguchi N, Takabe S, Goda T. De-phosphorylation of TRalpha-1 by p44/42 MAPK inhibition enhances T(3)-mediated GLUT5 gene expression in the intestinal cell line Caco-2 cells. Biochem Biophys Res Commun 359: 979-984, 2007.

112. Monteiro IM, Ferraris RP. Precocious enhancement of intestinal fructose uptake by diet in adrenalectomized rat pups. Pediatr Res 41: 353-358, 1997.

113. Monteiro IM, Jiang L, Ferraris RP. Dietary modulation of intestinal fructose transport and GLUT5 mRNA expression in hypothyroid rat pups. J Pediatr Gastroenterol Nutr 29: 563-570, 1999.

114. Montonen J, Jarvinen R, Knekt P, Heliovaara M, Reunanen A. Consumption of sweetened beverages and intakes of fructose and glucose predict type 2 diabetes occurrence. J Nutr 137: 1447-1454, 2007.

115. Nakagawa T, Hu H, Zharikov S, Tuttle KR, Short RA, Glushakova O, Ouyang X, Feig DI, Block ER, Herrera-Acosta J, Patel JM, Johnson RJ. A causal role for uric acid in fructose-induced metabolic syndrome. Am J Physiol Renal Physiol 290: F625-F631, 2006.

116. Nobigrot T, Chasalow FI, Lifshitz F. Carbohydrate absorption from one serving of fruit juice in young children: age and carbohydrate composition effects. J Am Coll Nutr 16: 152-158, 1997. 
117. Nualart F, Godoy A, Reinicke K. Expression of the hexose transporters GLUT1 and GLUT2 during the early development of the human brain. Brain Res 824: 97-104, 1999.

118. Ogawa J, Inoue H, Koide S. Glucose-transporter-type-I-gene amplification correlates with sialyl-Lewis-X synthesis and proliferation in lung cancer. Int J Cancer 74: 189-192, 1997.

119. Oldendorf WH. Brain uptake of radiolabeled amino acids, amines, and hexoses after arterial injection. Am J Physiol 221: 1629-1639, 1971.

120. Pagliassotti MJ, Horton TJ. Sucrose, insulin action and biologic complexity. Recent Res Devel Physiol 2: 337-353, 2004.

121. Park SH, Lee YJ, Lim MJ, Kim EJ, Lee JH, Han HJ. High glucose inhibits fructose uptake in renal proximal tubule cells: involvement of cAMP, PLC/PKC, p44/42 MAPK, and cPLA2. J Cell Physiol 200: 407-416, 2004

122. Payne J, Maher F, Simpson I, Mattice L, Davies P. Glucose transporter Glut 5 expression in microglial cells. Glia 21: 327-331, 1997.

123. Pelicano H, Martin DS, Xu RH, Huang P. Glycolysis inhibition for anticancer treatment. Oncogene 25: 4633-4646, 2006.

124. Pitkanen E. Mannose, mannitol, fructose and 1,5-anhydroglucitol concentrations measured by gas chromatography/mass spectrometry in blood plasma of diabetic patients. Clin Chim Acta 251: 91-103, 1996.

125. Raichur S, Lau P, Staels B, Muscat GE. Retinoid-related orphan receptor gamma regulates several genes that control metabolism in skeletal muscle cells: links to modulation of reactive oxygen species production. J Mol Endocrinol 39: 29-44, 2007.

126. Rand EB, Depaoli AM, Davidson NO, Bell GI, Burant CF. Sequence, tissue distribution, and functional characterization of the rat fructose transporter GLUT5. Am J Physiol Gastrointest Liver Physiol 264: G1169-G1176, 1993.

127. Rigau T, Rivera M, Palomo MJ, Fernandez-Novell JM, Mogas T, Ballester J, Pena A, Otaegui PJ, Guinovart JJ, Rodriguez-Gil JE. Differential effects of glucose and fructose on hexose metabolism in dog spermatozoa. Reproduction 123: 579-591, 2002.

128. Roberts ES, Zandonatti MA, Watry DD, Madden LJ, Henriksen SJ, Taffe MA, Fox HS. Induction of pathogenic sets of genes in macrophages and neurons in NeuroAIDS. Am J Pathol 162: 2041-2057, 2003

129. Rogers S, Macheda ML, Docherty SE, Carty MD, Henderson MA, Soeller WC, Gibbs EM, James DE, Best JD. Identification of a novel glucose transporter-like protein-GLUT-12. Am J Physiol Endocrinol Metab 282: E733-E738, 2002.

130. Rutledge AC, Adeli K. Fructose and the metabolic syndrome: pathophysiology and molecular mechanisms. Nutr Rev 65: S13-23, 2007.

131. Ryder JW, Kawano Y, Chibalin AV, Rincon J, Tsao TS, Stenbit AE, Combatsiaris T, Yang J, Holman GD, Charron MJ, Zierath JR. In vitro analysis of the glucose-transport system in GLUT4-null skeletal muscle. Biochem J 342: 321-328, 1999.

132. Sanchez-Lozada LG, Tapia E, Bautista-Garcia P, Soto V, AvilaCasado C, Vega-Campos IP, Nakagawa T, Zhao L, Franco M, Johnson RJ. Effects of febuxostat on metabolic and renal alterations in rats with fructose-induced metabolic syndrome. Am J Physiol Renal Physiol 294: F710- F718, 2008

133. Sancho S, Casas I, Ekwall H, Saravia F, Rodriguez-Martinez H, Rodriguez-Gil JE, Flores E, Pinart E, Briz M, Garcia-Gil N, Bassols J, Pruneda A, Bussalleu E, Yeste M, Bonet S. Effects of cryopreservation on semen quality and the expression of sperm membrane hexose transporters in the spermatozoa of Iberian pigs. Reproduction 134: $111-121,2007$

134. Sancho S, Casas I, Pinart E, Briz M, Garcia-Gil N, Bassols J, Pruneda A, Bussalleu E, Yeste M, Flores E, Rodriguez-Gil J, Ekwall H, Rodriguez-Martinez H, Bonet S. OC1 effects of cryopreservation on the expression of Glut-3, Glut-5 and As-A proteins in Iberian boar sperm membranes. Reprod Domest Anim 41, Suppl 2: 103, 2006.

135. Sasaki A, Yamaguchi H, Horikoshi Y, Tanaka G, Nakazato Y. Expression of glucose transporter 5 by microglia in human gliomas. Neuropathol Appl Neurobiol 30: 447-455, 2004.

136. Shepherd EJ, Helliwell PA, Mace OJ, Morgan EL, Patel N, Kellett GL. Stress and glucocorticoid inhibit apical GLUT2-trafficking and intestinal glucose absorption in rat small intestine. J Physiol 560: 281290, 2004.

137. Shepherd PR, Gibbs EM, Wesslau C, Gould GW, Kahn BB. Human small intestine facilitative fructose/glucose transporter (GLUT5) is also present in insulin-responsive tissues and brain. Investigation of biochemical characteristics and translocation. Diabetes 41: 1360-1365, 1992.
138. Shu HJ, Isenberg K, Cormier RJ, Benz A, Zorumski CF. Expression of fructose sensitive glucose transporter in the brains of fructose-fed rats. Neuroscience 140: 889-895, 2006.

139. Shu R, David ES, Ferraris RP. Dietary fructose enhances intestinal fructose transport and GLUT5 expression in weaning rats. Am J Physiol Gastrointest Liver Physiol 272: G446-G453, 1997.

140. Shu R, David ES, Ferraris RP. Luminal fructose modulates fructose transport and GLUT-5 expression in small intestine of weaning rats. Am J Physiol Gastrointest Liver Physiol 274: G232-G239, 1998.

141. Siddiqui N, Mangus DA, Chang TC, Palermino JM, Shyu AB, Gehring K. Poly(A) nuclease interacts with the C-terminal domain of polyadenylate-binding protein domain from poly(A)-binding protein. J Biol Chem 282: 25067-25075, 2007.

142. Simpson IA, Carruthers A, Vannucci SJ. Supply and demand in cerebral energy metabolism: the role of nutrient transporters. J Cereb Blood Flow Metab 27: 1766-1791, 2007.

143. Stuart CA, Howell ME, Yin D. Overexpression of GLUT5 in diabetic muscle is reversed by pioglitazone. Diabetes Care 30: 925-931, 2007.

144. Stuart CA, Yin D, Howell ME, Dykes RJ, Laffan JJ, Ferrando AA. Hexose transporter mRNAs for GLUT4, GLUT5, and GLUT12 predominate in human muscle. Am J Physiol Endocrinol Metab 291: E1067E1073, 2006

145. Sugawara-Yokoo M, Suzuki T, Matsuzaki T, Naruse T, Takata K. Presence of fructose transporter GLUT5 in the S3 proximal tubules in the rat kidney. Kidney Int 56: 1022-1028, 1999.

146. Tavakkolizadeh A, Ramsanahie A, Levitsky LL, Zinner MJ, Whang EE, Ashley SW, Rhoads DB. Differential role of vagus nerve in maintaining diurnal gene expression rhythms in the proximal small intestine. J Surg Res 129: 73-78, 2005.

147. Thiesen A, Wild GE, Keelan M, Clandinin MT, Thomson AB. Locally and systemically active glucocorticosteroids modify intestinal absorption of sugars in rats. J Appl Physiol 94: 583-590, 2003.

148. Toloza EM, Diamond J. Ontogenetic development of nutrient transporters in rat intestine. Am J Physiol Gastrointest Liver Physiol 263: G593G604, 1992.

149. Uldry M, Thorens B. The SLC2 family of facilitated hexose and polyol transporters. Pflügers Arch 447: 480-489, 2004.

150. Valois S, Rising R, Duro D, Cole C, Cedillo M, Lifshitz F. Carbohydrate malabsorption may increase daily energy requirements in infants. Nutrition 19: 832-836, 2003.

151. Vannucci S.J, Maher F, Simpson IA. Glucose transporter proteins in brain: delivery of glucose to neurons and glia. Glia 21: 2-21, 1997.

152. Warburg O. On the origin of cancer cells. Science 123: 309-314, 1956

153. Wasserman D, Hoekstra JH, Tolia V, Taylor CJ, Kirschner BS, Takeda J, Bell GI, Taub R, Rand EB. Molecular analysis of the fructose transporter gene (GLUT5) in isolated fructose malabsorption. J Clin Invest 98: 2398-2402, 1996

154. Wood IS, Trayhurn P. Glucose transporters (GLUT and SGLT): expanded families of sugar transport proteins. Br J Nutr 89: 3-9, 2003.

155. Wood IS, Wang B, Lorente-Cebrian S, Trayhurn P. Hypoxia increases expression of selective facilitative glucose transporters (GLUT) and 2-deoxy-D-glucose uptake in human adipocytes. Biochem Biophys Res Commun 361: 468-473, 2007.

156. Younes M, Brown RW, Mody DR, Fernandez L, Laucirica R. GLUT1 expression in human breast carcinoma: correlation with known prognostic markers. Anticancer Res 15: 2895-2898, 1995.

157. Younes M, Lechago LV, Somoano JR, Mosharaf M, Lechago J. Immunohistochemical detection of Glut3 in human tumors and normal tissues. Anticancer Res 17: 2747-2750, 1997.

158. Zamora-Leon SP, Golde DW, Concha II, Rivas CI, Delgado-Lopez F, Baselga J, Nualart F, Vera JC. Expression of the fructose transporter GLUT5 in human breast cancer. Proc Natl Acad Sci USA 93: 1847-1852, 1996.

159. Zhao FQ, Glimm DR, Kennelly JJ. Distribution of mammalian facilitative glucose transporter messenger RNA in bovine tissues. Int J Biochem 25: 1897-1903, 1993.

160. Zhao FQ, Okine EK, Cheeseman CI, Shirazi-Beechey SP, Kennelly JJ. Glucose transporter gene expression in lactating bovine gastrointestinal tract. J Anim Sci 76: 2921-2929, 1998.

161. Zierath JR, Nolte LA, Wahlstrom E, Galuska D, Shepherd PR, Kahn BB, Wallberg-Henriksson H. Carrier-mediated fructose uptake significantly contributes to carbohydrate metabolism in human skeletal muscle. Biochem J 311: 517-521, 1995. 